\title{
Key aroma components of a dry cured sausage with high fat content (sobrassada)
}

\author{
M. P. Gianelli ${ }^{1,2}$, A. Olivares ${ }^{1}$ and M. Flores ${ }^{1 *}$ \\ ${ }^{1}$ Instituto de Agroquímica y Tecnología de Alimentos (CSIC), PO Box 73, 46100 Burjassot, Valencia, \\ Spain. ${ }^{2}$ Department of Food Engineering, Universidad del Bío-Bío. P.O. box 447, Chillán, Chile
}

The key aroma components and the lipolysis in a dry cured sausage "Sobrassada of Mallorca from black pig" were studied. Sobrassada was characterized by a fatty acid profile with a high content of monounsaturated fatty acids and by the generation during the curing process of polyunsaturated free fatty acids that were oxidized to generate flavour compounds. Eighty four different volatile compounds were identified and 3 of them were for the first time detected in dry sausages (methyl nonanoate, 1-methyl-1H-pyrrole and 2-acetyl pyrrole). Thirty five different aroma active zones were found. The aroma of sobrassada was not only due to compounds already detected as essential contributors in dry sausages (3-methyl butanoic acid, ethyl 3-methyl butanoate, 2, 3-butanedione and acetic acid) but also to other compounds such as ethyl octanoate, furfural, benzaldehyde, (Z)-2nonenal, 4-methyl-phenol, delta-hexalactone, heptanoic acid, 2-pentylfuran and 2-acetyl-pyrrole which gave specific aroma notes.

Keywords: aromas, fermentation, GC-olfactory, fatty acids, sausages

\section{$<1>$ INTRODUCTION}

Sobrassada is a dry cured meat product originally made in the island of Mallorca (Spain) consisting of lean pork meat (30-60\%), a high percentage of white fat (40-70\%) and additives such as curing agents, salt, nitrate and nitrite and spices, such as paprika, pepper, origanum and others (Eim et al., 2008). The development of the typical sensory characteristics is achieved by grinding and kneading the raw materials until a fine paste is obtained and then, the mixture is filled into casing and left to ripen for several weeks under natural or controlled ripening conditions (Rosello et al., 1995). The ripening is performed at temperatures between 14 to $16{ }^{\circ} \mathrm{C}$ and relative humidity between $70-85 \%$ while the total ripening time will depend on the product diameter.

Sobrassada was established as a protected geographical indication (PGI) from the island of Mallorca and two different products were defined, Sobrassada of Mallorca and later, Sobrassada of Mallorca from black pig by the Consejo Regulador Sobrassada de Mallorca (http://www.sobrasadademallorca.org). This latest product was defined as a sobrassada exclusively processed using meat from Mallorca black pig and filled into natural casings. It is remarkable the

\footnotetext{
* To whom correspondence should be sent (e-mail: mflores@iata.csic.es).

Received: 13 October 2009; revised: 12 January 2010.
} 
aroma of the sobrassada that differs from the aroma detected in other dry cured meat products. The few studies performed in sobrassada have been related with its chemical composition (Rosello et al., 1995), textural properties (Llull et al., 2002a, b) and the addition of fibre (Eim et al., 2008). However, the compounds responsible of its aroma have not been studied.

Research in the aroma of dry cured sausages has identified a high number of volatile compounds (Ansorena et al., 2001; Marco et al., 2006). Several studies determined the contribution of these volatile compounds to the aroma of the sausages using olfactometry techniques that allowed the elucidation of the chemical structures producing the aroma notes (Schmidt and Berger, $1998 \mathrm{a}, \mathrm{b}$; Meynier et al., 1999; Marco et al., 2007). Recently, Söllner and Schieberle (2009) identified 51 key aroma compounds in an Hungarian salami. However, so far there are not studies on sobrassada neither on sobrassada from black pig that can elucidate which are the compounds producing its superior aroma.

Sobrassada is a meat product rich in lipids due to its high content in pork fat. In meat products, the lipids are hydrolysed by lipases generating free fatty acids (Gandemer et al., 2002). During the ripening process, the oxidation of unsaturated free fatty acids generates volatile compounds that affect the flavour of the meat product (Ordoñez et al., 1999). The lipid composition of the meat product as well as the lipolysis process will affect its final flavour that in the case of Sobrassada of Mallorca from black pig could be essential to explain its characteristic aroma.

The production of traditional foods with a protected geographical indication (PGI) not only meets consumer demands for less processed foods, also these products have a high aroma quality. The knowledge of the composition of the key aroma compounds present in sobrassada can help to optimise the manufacture by controlling the generation of the key aroma compounds. Therefore our purpose was to elucidate which are these key aroma compounds in sobrassada of Mallorca from black pig and to study the contribution of the lipolysis to the generation of the key aroma compounds.

\section{$<$ 1 $>$ MATERIALS AND METHODS}

\section{$<2>$ Materials}

\section{$<3>$ Sobrassada dry cured sausage samples}

Traditional dry cured sausages "sobrassada of Mallorca from black pig", PGI (El Zagal, Felanitx, Mallorca, Spain) were purchased from a local supermarket. The sausages were manufactured under the traditional specifications. They consisted on pork meat, fat belly, salt, paprika and spices, sugars, sodium nitrite, potassium nitrate and antioxidants; butylhydroxy toluene, butylhydroxy anisole and propyl galate. The sobrassada sausages were dried for approximately 1 month. The weight of each sobrassada sausage was approximately $700 \mathrm{~g}$ and the diameter ranged from 50 to $60 \mathrm{~mm}$. Three sausages (S1, S2, S3) from different batches of the same manufacturer were 
sliced and directly used for $\mathrm{pH}$, water activity and moisture analyses. Then, the remaining slices were vacuum packed and frozen at $-20{ }^{\circ} \mathrm{C}$ for protein, lipid and volatile compound analyses.

\section{$<$ 2> Methods}

$<3>$ Chemical analyses ( $\mathrm{pH}$, water activity, moisture, protein, total lipids)

The $\mathrm{pH}$ was measured by introducing a portable pH-meter (HI 99163, Hanna Intruments Inc., Hoonsocket, USA) into a mixture of sobrassada and water (1:1) (ISO 2917, 1974). The water activity (Aw) was analysed using a FAst-lab water activity meter (Gbx, Romans sur Isère Cédex, France), previously calibrated with sodium chloride and potassium sulphate.

Moisture content was determined according to the official method for analysis of meat products $\mathrm{BOE}(\mathrm{BOE}, 1979)$ by dehydration at $100^{\circ} \mathrm{C}$ until constant weight. Nitrogen content was determined by the Kjeldahl method and protein estimated by multiplying the nitrogen content by 6.25 . Total lipids were extracted from $5 \mathrm{~g}$ of sobrassada sample according to the method of Folch et al., (1957), using dichloromethane:methanol (2:1) instead of chloroform:methanol (2:1). The extracts were dried in a rotating vacuum evaporator and weighed to determine the total lipid content. The chemical analyses of each sobrassada sample were done in triplicate and results were expressed as the mean in dry matter.

\section{$<3>$ Total fatty acid composition and free fatty acid analysis}

Fatty acid methyl esters (FAME) of total lipids were prepared as described by Berry et al. (1965). Free fatty acids were determined in total lipids as described by Gandemer et al. (1991). The free fatty acids (FFA) were separated from the lipid fraction using an ion exchange resin, as described by Needs et al. (1983). Heneicosanoic acid (C21:0) was used as the internal standard. FFAs were converted into FAME using boron fluoride-methanol (Sigma-Aldrich, Chemical Co., Milwaukee, WI) as the methylating reagent. Analysis of the FAME was carried out in a Fisons 816 gas chromatograph (GC) equipped with a flame ionisation detector and a split injector (split ratio used 2:1). The capillary column was a CP-sil 88 (Agilent, Las Rozas, Spain; 100 m, $0.25 \mathrm{~mm}$ i.d., $0.2 \mu \mathrm{m}$ film thickness). The oven temperature program began at $140{ }^{\circ} \mathrm{C}$ for $10 \mathrm{~min}$, ramped to $190{ }^{\circ} \mathrm{C}$ at $4{ }^{\circ} \mathrm{C} / \mathrm{min}$, held at $190{ }^{\circ} \mathrm{C}$ for $10 \mathrm{~min}$, ramped to $220^{\circ} \mathrm{C}$ at $2{ }^{\circ} \mathrm{C} / \mathrm{min}$, held at 220 for $5 \mathrm{~min}$, ramped to 230 at $2{ }^{\circ} \mathrm{C} / \mathrm{min}$ and finally, held at $230{ }^{\circ} \mathrm{C}$ for $20 \mathrm{~min}$. Detector and injector temperatures were 240 and $220^{\circ} \mathrm{C}$ respectively. The individual fatty acids were identified by comparing their retention times with those of standard fatty acid methyl esters. For quantification, the response factors of a standard FAME mixture were calculated.

$<3>$ Volatile compounds analysis 
Extraction of headspace volatile compounds was done using a solid phase microextraction (SPME) device (Supelco, Bellefonte, PA, USA) with a $85 \mu$ m carboxen, polydimethylsiloxane StableFlex fibre (CAR/PDMS SF). For each experiment, $3 \mathrm{~g}$ of minced sausage was weighted into a $10 \mathrm{~mL}$ headspace vial. The vial was left for $30 \mathrm{~min}$ in a thermoblock (J.P., Selecta, Barcelona, Spain) at $37^{\circ} \mathrm{C}$ for equilibration. The CAR/PDMS fibre was then exposed to the headspace for $3 \mathrm{~h}$ while maintaining the sample at $37^{\circ} \mathrm{C}$.

For the identification and quantification of the volatile compounds, a gas chromatograph HP 7890A equipped with an HP 5975C mass selective detector (Hewlett Packard, Palo Alto, CA) was used. The compounds adsorbed by the fibre were desorbed in the injection port of the GC-MS for 15 min at $220^{\circ} \mathrm{C}$ with the purge valve off (splitless mode). The compounds were separated on a DB-624 capillary column J \& W Scientific (Agilent Technologies, USA) and analyzed as described Marco et al. (2006). The compounds were identified by comparison with mass spectra from the library database (Nist' 98), kovats retention index (Kovats, 1965) and by comparison with authentic standards. Each volatile compound was quantified using the area of a target ion to avoid coelution. Then, each volatile compound was expressed as the percentage of the total extracted area. The volatile analysis of each sobrassada sample was done in triplicate.

\section{$<3>$ Gas chromatrography-olfactometry}

The volatile compounds were adsorbed by the SPME fibre as described above but using $4 \mathrm{~g}$ of sobrassada as sample weight. Then, the fibre was desorbed in the gas chromatograph (Agilent 6890, USA) injection port for $6 \mathrm{~min}$ at $240{ }^{\circ} \mathrm{C}$ in splitless mode; the split valve was opened after $1 \mathrm{~min}$. The compounds were separated using a DB-624 capillary column (J\&W Scientific, $60 \mathrm{~m}, 0.32 \mathrm{~mm}$ i.d., film thickness $1.8 \mu \mathrm{m})$. The capillary column was split (2:1) into deactivated and uncoated capillary tubing connected with the sniffing port (ODP3, Gerstel, Mülheim an der Ruhr, Germany) and flame ionization detector (FID), respectively. The sniffing port ODP3 was equipped with a humidified air make up and a computer voice recorder integrated in the Chemstation software (Agilent, USA). Helium was used as the carrier gas with a linear velocity of $35.14 \mathrm{~cm} / \mathrm{s}$. Then, the volatile compounds were separated using a temperature programme and after the injection of the fibre the oven was held at $38^{\circ} \mathrm{C}$ for $13 \mathrm{~min}$, ramped at $100{ }^{\circ} \mathrm{C}$ at $3{ }^{\circ} \mathrm{C} / \mathrm{min}$ and maintained at $100{ }^{\circ} \mathrm{C}$ during $10 \mathrm{~min}$, then to $150{ }^{\circ} \mathrm{C}$ at $3{ }^{\circ} \mathrm{C} / \mathrm{min}$ and to $210{ }^{\circ} \mathrm{C}$ at $5{ }^{\circ} \mathrm{C} / \mathrm{min}$ and finally held at $210^{\circ} \mathrm{C}$ for $20 \mathrm{~min}$, the total run time was $82.3 \mathrm{~min}$. Detector temperature was set at $240{ }^{\circ} \mathrm{C}$.

The detection frequency method was used to estimate the aromatic impact of each volatile compound (Linssen et al., 1993; Pollien et al., 1997). Three trained assessors evaluated the odours from the GC-effluent. A total of 6 assessments were carried out. For each assessment, evaluation of the odour took place over two different time intervals (0-35 and 35-70 min) in order to avoid olfactory fatigue of the assessors. The final detection frequency value (DF) for each compound was obtained by summation of the 6 sniffings. Aroma compounds were identified by three different ways; comparison 
with mass spectra and Kovats retention indices (Kovats, 1965); comparison with the retention times of authentic standards injected in the GC-FID; and by coincidence of the assessors descriptors with those in the Fenaroli's handbook of flavour ingredients (Burdock, 2002) and in the Flavournet (Acree and Arn, 2004).

\section{$<3>$ Statistical analysis}

The differences among the sobrassada sausages were determined by one-factor analysis of variance (ANOVA) using the statistic software Statgraphics plus (v 5.1). Significant effects were compared using Fisher's least significant difference (LSD) test.

\section{$<1>$ RESULTS AND DISCUSSION}

\section{$<2>$ Compositional data}

The three Sobrassada of Mallorca from black pig batches have similar protein and fat contents which ranged from 12.7 to $15.3 \%$ protein and 55.1 to $57.6 \%$ fat (Table 1). The batch S1 contained higher significant humidity content than the other batches and also it was observed a higher water activity value in $\mathrm{S} 1$ than in the others. There were no differences in $\mathrm{pH}$ value among batches. These values are in accordance with the values recommended for the PGI which indicate a $\mathrm{pH}$ value lower than 4.5 or water activity lower than 0.91 .

\section{$<2>$ Free fatty acids and lipolyisis}

Total fatty acid composition in Sobrassada of Mallorca from black pig was not different among batches (Table 2). The three batches were not different in the three main groups of fatty acids (saturated, monounsaturated and polyunsaturated). The main acids were palmitic (23\%), stearic $(10 \%)$, oleic $(50 \%)$ and linoleic (8\%). Total saturated fatty acids were about $34-35 \%$, monounsaturated $54-55 \%$ and polyunsaturated $10 \%$. The similarities among batches are probably due because the raw material used comes from the same genetic line (black pigs).

The free fatty acids (FFA) detected in Sobrassada had different proportions than the obtained for the total fatty acid concentration (Table 3). The three batches only showed differences in the concentration of saturated free fatty acids. The batch S1 had a higher significant concentration of free saturated fatty acids than S2 and S3. However, there were not differences among batches in the content of free mono and polyunsaturated fatty acids. FFA was about 22-23\% saturated, 61-62 monunsaturated and $16 \%$ polyunsaturated. The proportion of FFA in contrast to the total fatty acid composition was higher in polyunsaturated FFA and, in lower proportion, monounsaturated ones. This specific liberation of polyunsaturated FFA has been reported in fermented sausages (Zanardi et al., 2004; Marco et al., 2006) and in subcutaneous adipose tissue of dry-cured ham (Antequera et al., 1993). However, the FFA reported in sobrassada by Eim et al. (2008) were different from the ones 
found in Sobrassada of Mallorca from black pig. Eim et al. (2008) detected higher contents of free mono and polyunsaturated fatty acids and probably, the reason is the different lean and fat tissues used as indicated Zanardi et al. (2004) when they compared different formulations of fermented sausages. The oxidation of unsaturated FFA will happen during the curing process and it is responsible of the generation of flavour compounds (Ordoñez et al., 1999).

\section{$<2>$ Aroma analysis}

The extraction of volatile compounds from the headspace of Sobrassada of Mallorca from black pig using SPME indicated the presence of high number of volatile compounds (Figure 1). From all the compounds extracted, 84 were identified by mass spectrometry (Table 4). All of them have been previously detected in fermented sausages (Ansorena et al., 2001; Marco et al., 2006; Meynier et al., 1999; Stahnke, 1994) except 3 compounds; methyl nonanoate, 1-methyl-1H-pyrrole and 2-acetyl pyrrole. The chemical identification of these 3 compounds detected for first time in sobrassada was confirmed using authentic standards (Table 4).

The 84 compounds identified corresponded to different chemical classes, 13 esters $(6-17 \%$ of the total extracted area), 13 aldehydes (0.6-1.1\%), 13 alcohols (12-13\%), 11 ketones (5-12\%), 6 carboxylic acids (27-48\%), 2 sulphur compounds (0.04-0.07\%), 6 heterocyclic compounds (0.6$0.7 \%), 5$ alyphatic hydrocarbons (1.2-1.8\%), 5 aromatic hydrocarbons (8-31\%), 8 compounds derived from spices (3-5\%) and 2 antioxidant compounds (1.7-2.1\%). The most abundant compounds were acetic acid (26-47\%), toluene (7-29\%), ethyl acetate (10-3.5\%), 2,3-butanediol (3.5-5.5\%), 1-propanol (1.5-3.8\%), 2-heptanone (1.5-5.3\%) and 2-nonanone (0.4-2.7\%). However, the abundance of the volatile compounds is highly affected by the affinity of the fiber used, in this case the CAR/PDMS fibre. Therefore, these results can only be compared with those results obtained using the same extractions conditions. Therefore, studies on the aroma of fermented sausages using SPME and the same CAR/PDMS fibre (Marco et al., 2006; Flores et al., 2004; Marco et al., 2008) showed also a high abundance of acetic acid, 2,3-butanediol and ethyl acetate in fermented sausages. Moreover, these authors detected a high abundance of aldehydes in dry sausages that were higher than in sobrassada that only contained around $1 \%$ of the total extracted area. This low aldehyde proportion can be explained by the presence of antioxidants, BHT and BHA, in the sobrassada samples while the fermented sausages studied by Marco et al. (2006, 2008) and Flores et al. (2004), did not contain antioxidants and also they were manufactured without spices.

On the other hand, the abundance of compounds in the three sobrassada batches was very similar except for the batch S1. The S1 batch showed a lower abundance of ester compounds and acids while presented a high abundance of aromatic hydrocarbons, pyrazines and ketones. In particular, S1 contained higher significant abundance than the other batches of several compounds; toluene, benzene, 2, 6-dimethyl pyrazine, propyl benzene, 2-octanone and 2-nonanone while it contained lower abundances of acetic acid, ethyl propionate, propyl actetate, methyl butyrate and 
other compounds (table 4). These differences in the content of volatile compounds could be related with the differences obtained in the content of moisture and free saturated fatty acids in S1 as indicated above.

In order to elucidate which compounds contribute to the aroma of sobrassada an olfactometry analysis was performed. Thirty five different aroma active zones were detected (figure 1, table 4), of them, thirty compounds were identified by matching mass spectra, linear retention indices and odour descriptions from references however, 5 of them were not identified. The identified odour active compounds belonged to different chemical classes; 7 were aldehydes, 4 esters, 4 alcohols, 4 carboxylic acids, 4 heterocyclic compounds, 3 ketones, 2 sulfur compounds and 2 terpenes. Many of these compounds were also detected as aroma active compounds in dry sausages (Schmidt and Berger, 1998a, b; Marco et al., 2007; Söllner and Schieberle, 2009). However, several of them have been identified for the first time as aroma active compounds in dry sausages; ethyl octanoate, 2 methyl-propanal, furfural, benzaldehyde, 1-propanol, 6-methyl-5-hepten-2-one, delta-hexalactone, tetramethyl-pyrazine, 1-methyl-1-H-pyrrole, acetyl-pyrrole, 3-carene and hexanoic acid although, this latest compound eluted together with $\alpha$-terpinene.

The contribution of the compounds to the aroma of sobrassada can be evaluated by their detection frequency values (DF in table 4) that is the number of times that the volatile compound has been detected by the panelists. The highest DF value indicates a highest contribution of the volatile compound to the aroma of the product (Linssen et al., 1993; Pollien et al., 1997). The compounds that showed the highest DF values in sobrassada were ethyl 3-methylbutanoate, ethyl octanoate, furfural, benzaldehyde, (Z)-2-nonenal, 4-methyl-phenol, delta-hexalactone, acetic, 3-methyl-butanoic and heptanoic acids, 2-pentylfuran and 2-acetyl-pyrrole. In addition, 5 compounds contribute to the aroma with meaty notes such as ethyl octanoate, furfural, (Z)-2-nonenal, dimethyldisulfide and 1-methyl-1Hpyrrole.

This is the first time that the aroma active compounds of sobrassada have been identified. However, previous studies of aroma active compounds in dry sausages indicated that the most potent odourants were 3-methylbutanoic acid, ethyl butanoate, propyl 3-methyl butanoate, 2, 3-butanedione and acetic acid (Schmidt and Berger, 1998 a, b). Also, Marco et al. (2007) indicated the contribution of acetic acid, ethyl butanoate, 3-methylbutanoic acid and hexanal as potent odourants. Recently, Söllner and Schieberle (2009) elucidated the odour activity values (OAV) of aroma compounds in Hungarian salami. This odour-activity value $(\mathrm{OAV})$ is a criterion for the selection of the most important aroma compounds in a food and they are calculated using the concentration and the odour threshold of the aroma compound (De Roos, 2007). Several compounds with highest OAV in hungarian salami (Söllner and Schieberle, 2009) were also detected in sobrassada such as acetic acid, acetaldehyde, methional, phenylacetaldehyde, 3-methyl butanoic acid and 4-methyl-phenol.

In 2009, Olivares et al. determined the contribution of volatile compounds to the aroma of dry fermented sausages processed without spices by calculating the OAV in oil and air. The compounds 
with highest oil OAV were 2, 3-butanedione, ethyl 2-methyl butanoate, ethyl 3-methyl butanoate, hexanal and 3-methyl butanoic acid. However, the aroma perceived in the headspace was due to compounds with the highest air OAVs such as 3-methyl butanoic acid, ethyl 2-methyl butanoate, nonanal and octanal.

In summary, several compounds have been always detected as essential contributors to the aroma of dry sausages, 3-methyl butanoic acid, ethyl 3-methyl butanoate, 2, 3-butanedione and acetic acid. Moreover, the aroma of sobrassada of Mallorca from black pig was characterized by the presence of these volatile compounds and also other compounds such as ethyl octanoate, furfural, benzaldehyde, (Z)-2-nonenal, 4-methyl-phenol, delta-hexalactone, heptanoic acid, 2-pentylfuran and 2-acetyl-pyrrole which were responsible of specific aroma notes with high DF values.

The results suggest that the key aroma compounds were generated from the fermentation process (acetic acid and 2,3-butanedione), amino acid degradation products (3-methyl butanoic acid, ethyl 3-methyl butanoate, benzaldehyde), lipid autoxidation process (furfural, (Z)-2-nonenal, deltahexalactone, heptanoic acid, 2-pentylfuran and 2-acetyl-pyrrole) and many other compounds from spices. In general, the contribution of the lipid autoxidation process to the aroma of sobrassada was important due to the presence of compounds not previously detected as key aroma compounds in dry sausages.

\section{$<1>$ CONCLUSION}

Sobrassada of Mallorca from black pig was characterized by a fatty acid profile with a high content of monounsaturated fatty acids and by the generation during the curing process of polyunsaturated free fatty acids that were oxidized to generate flavour compounds. The key aroma compounds of sobrassada were identified and several of them have been always detected as essential contributors to the aroma of dry sausages, 3-methyl butanoic acid, ethyl 3-methyl butanoate, 2,3butanedione and acetic acid. In addition, the aroma of sobrassada of Mallorca from black pig was due to the presence of another compounds such as ethyl octanoate, furfural, benzaldehyde, (Z)-2-nonenal, 4-methyl-phenol, delta-hexalactone, heptanoic acid, 2-pentylfuran and 2-acetyl-pyrrole which gave specific aroma notes.

\section{$<$ 1>ACKOWLEDGEMENTS}

Financial support from AGL 2009-08787 from MCINN (Spain) and FEDER funds are fully acknowledged. MP Gianelli thanks the FONDECYT for the 11070128 (Chile). The pre-doctoral schorlarship from GVA (Generalitat Valenciana, Spain) to A. Olivares is also acknowledged. Authors are grateful to M. P. Valero for technical assistance.

\section{$<$ 1 $>$ REFERENCES}


Acree T. and Arn H. (2004). Flavournet and human odour space. Gas chromatography - olfactometry (GCO) of natural products. Available at http://www.flavournet.org (consulted 17 December 2010). Ansorena D., Gimeno O., Astiasaran I. and Bello J. (2001). Analysis of volatile compounds by GCMS of a dry fermented sausage: chorizo de Pamplona. Food Research International 34: 67-75. Antequera T., Cordoba J.J., Ruiz J., Martin L., Garcia C., Bermudez M.E. and Ventanas J. (1993). Free Fatty-Acids During the Ripening of Iberian Ham. Revista Española de Ciencia y Tecnología de Alimentos 33: 197-208.

Berry J.F., Cevallos W.H. and Wade R.R.J. (1965). Lipid class and fatty acid composition of intact peripheral nerve and during walerian degeneration. Journal of American Oil and Chemistry Society 42: 492-495.

BOE (1979). Métodos Oficiales de Análisis de Productos Cárnicos. Boletín Oficial del Estado 28 de agosto de 1979, Anexo II, 20233-20240. Madrid, Spain.

Burdock G.A. (2002). Fenaroli's Handbook of Flavour Ingredients, 4th edn., Boca Raton, Florida: CRC Press Inc., pp. 355-356.

De Roos K. (2007). Selecting the right flavourings for a food product. In: A. Taylor and Hort Joanne (eds). Modifying flavour in food. London, UK: Woodhead Publishing Ltd., pp. 243-273.

Eim V.S., Simal S., Rossello C. and Femenia A. (2008). Effects of addition of carrot dietary fibre on the ripening process of a dry fermented sausage (sobrassada). Meat Science 80: 173-182.

Flores M., Dura M.A., Marco A. and Toldra F. (2004). Effect of Debaryomyces spp. on aroma formation and sensory quality of dry-fermented sausages. Meat Science 68: 439-446.

Folch J., Lees M. and Sloane Stanley G. H. (1957). A simple method for isolation and purification of total lipids from animal tissues. Journal of Biological Chemistry 226: 497-508.

Gandemer G. (2002). Lipids in muscles and adipose tissues, changes during processing and sensory properties of meat products. Meat Science 62: 309-321.

Gandemer G., Morvan-Mahi B., Meynier A. and Leperq M. (1991). Quantitative and qualitative analysis of free fatty acids in meat and meat products. Procedings of the International Congress of Meat Science and Technology 37: 1139-1142.

ISO 2917 (1974). Meat and Meat Products. Determination of the pH. Reference method. International Organization for Standardization.

Kovats E.S. (1965). Gas Chromatographic Characterization of Organic Substances in the Retention Index System. In: J. C. Giddings and R. A. Keller (ed.), Advances in Chromatography. New York: Marcel Dekker Inc., pp. 229-247.

Linssen J.P.H., Janssens J.L.G.M., Roozen J.P. and Posthumus M.A. (1993). Combined gas chromatography and sniffing port analysis of volatile compounds of mineral water packed in polyethylene laminated packages. Food Chemistry 46: 367-371.

Llull P., Simal S., Benedito J. and Rossello C. (2002a). Evaluation of textural properties of a meatbased product (sobrassada) using ultrasonic techniques. Journal of Food Engineering 53: 279-285. 
Llull P., Simal S., Femenia A., Benedito J. and Rossello C. (2002b). The use of ultrasound velocity measurement to evaluate the textural properties of sobrassada from Mallorca. Journal of Food Engineering 52: 323-330.

Marco A., Navarro J.L. and Flores M. (2006). The influence or nitrite and nitrate on microbial, chemical and sensory parameters of show dry fermented sausage. Meat Science 73: 660-673. Marco A., Navarro J.L. and Flores M. (2007). Quantification of Selected Odour-Active Constituents in Dry Fermented Sausages Prepared with Different Curing Salts. Journal of Agricultural and Food Chemistry 55: 3058-3065.

Marco A., Navarro J.L. and Flores M. (2008). The sensory quality of dry fermented sausages as affected by fermentation stage and curing agents. European Food Research and Technology 226: 449458.

Meynier A., Novelli E., Chizzolini R., Zanardi E. and Gandemer G. (1999). Volatile compounds of commercial Milano salami. Meat Science 51: 175-183.

Needs E.C., Ford G.D., Owen A.J., Tuckley B. and Anderson M. (1983). A method for the quantitative determination of individual free fatty acids in milk by ion exchange resin adsorption and gas-liquid chromatography. Journal of Dairy Research 50: 321-329.

Olivares A., Navarro J.L. and Flores M. (2009). Establishment of the contribution of volatile compounds to the aroma of fermented sausages at different stages of processing and storage. Food Chemistry 115: 1464-1472.

Ordóñez J.A., Hierro E.V., Bruna J.M. and de la Hoz L. (1999). Changes in the Components of DryFermented Sausages during Ripening. Critical Reviews in Food Science and Nutrition 39: 329-367. Pollien P., Ott A., Montigon F., Baumgartner M., Muñoz-Box R., Chaintreau A. (1997). Hyphenated headspace-gas chromatography-sniffing technique: screening of impact odourants and quantitative aromagram comparisons. Journal of Agricultural and. Food Chemistry 45: 2630-2637.

Rosello C., Barbas J.I., Berna A. and López N. (1995). Microbial and chemical changes in "Sobrasada" during ripening. Meat Science 40: 379-385.

Schmidt S. and Berger R.G. (1998a). Aroma compounds in fermented sausages of different origins. Food Science and Technology-Lebensmittel-Wissenschaft and Technologie 31: 559-567.

Schmidt S. and Berger R.G. (1998b). Microbially formed aroma compounds during the maturation of dry fermented sausage (Salami). Advances in Food Sciences 20: 144-152.

Söllner K. and Schieberle P. (2009). Decoding the Key Aroma Compounds of Hungarian-Type Salami by Molecular Sensory Science Approaches. Journal of Agricultural and Food Chemistry 57: 4319-4327.

Stahnke L.H. (1994). Aroma Components from Dried Sausages Fermented with StaphylococcusXylosus. Meat Science 38: 39-53. 
Key aroma components of sobrassada

Zanardi E., Ghidini S., Battaglia A. and Chizzolini R. (2004). Lipolysis and lipid oxidation in fermented sausages depending on different processing conditions and different antioxidants. Meat Science 66: 415-423. 


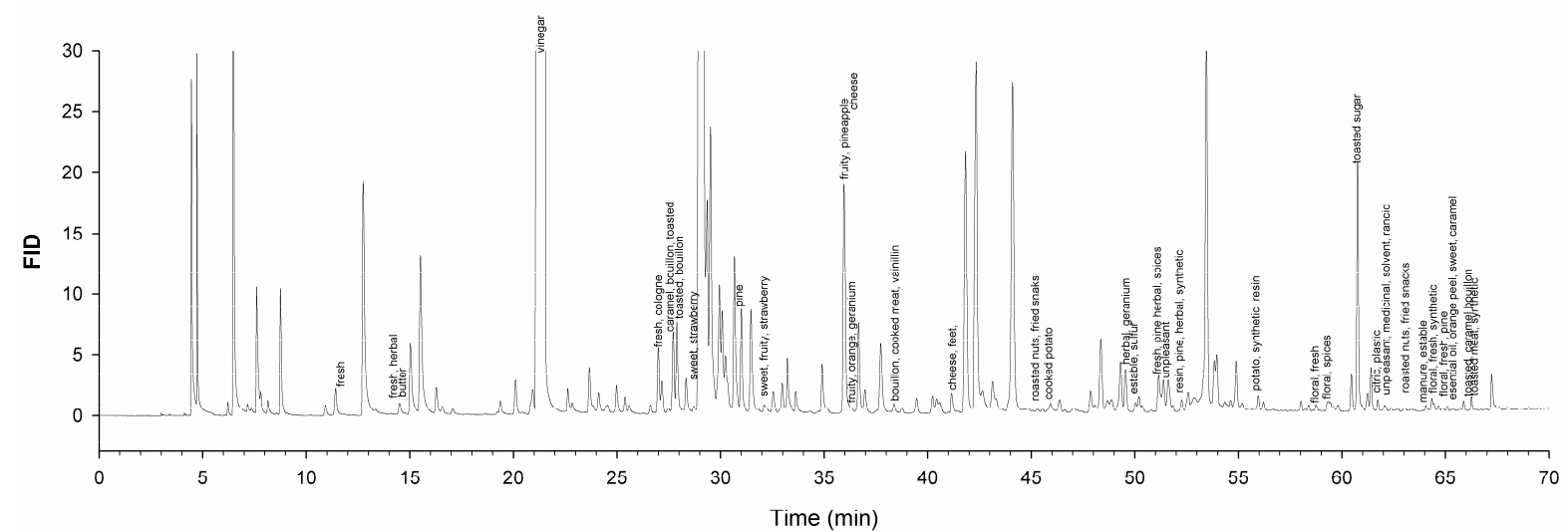

Figure 1. 
Table 1. Proximate composition, water activity and $\mathrm{pH}$ in sobrassada of Mallorca from black pig dry cured sausage.

\begin{tabular}{lrrrrr}
\hline & \multicolumn{3}{c}{ Sobrassada samples } & \multirow{2}{*}{ SEM $^{1}$} & \multirow{2}{*}{$p^{2}$} \\
\cline { 2 - 4 } & \multicolumn{1}{c}{$\mathrm{S} 1$} & \multicolumn{1}{c}{$\mathrm{S} 2$} & $\mathrm{~S} 3$ & & \\
\hline Moisture & $26.98 \mathrm{a}$ & $24.83 \mathrm{~b}$ & $24.13 \mathrm{~b}$ & 0.22 & 0.0002 \\
$(\%)$ & 55.13 & 57.11 & 57.64 & 0.83 & $\mathrm{~ns}$ \\
Fat (\%) & 14.09 & 12.74 & 15.32 & 1.56 & $\mathrm{~ns}$ \\
Protein (\%) & 4.57 & 4.56 & 4.56 & 0.1 & $\mathrm{~ns}$ \\
$\mathrm{pH}$ & $0.843 \mathrm{a}$ & $0.823 \mathrm{~b}$ & $0.814 \mathrm{~b}$ & 0.003 & 0.0153 \\
$\mathrm{a}_{\mathrm{w}}$ & & & & &
\end{tabular}

${ }^{\mathrm{T}}$ SEM: Standard error of the mean.

${ }^{2} p$ value denotes statistical significance among samples. Means followed by different letters are significant different; ns: non significant. 
Table 2. Total Fatty acid composition in sobrassada of Mallorca from black pig dry cured sausages.

\begin{tabular}{|c|c|c|c|c|c|}
\hline \multirow{2}{*}{$\begin{array}{l}\text { Fatty acids }^{1} \\
(\mathrm{mg} / 100 \mathrm{~g} \mathrm{dw})\end{array}$} & \multicolumn{3}{|c|}{ Sobrassada samples } & \multirow{2}{*}{$\mathrm{SEM}^{2}$} & \multirow{2}{*}{$p^{3}$} \\
\hline & $\mathrm{S} 1$ & $\mathrm{~S} 2$ & S3 & & \\
\hline C14:0 & 351.2 & 350.4 & 336.8 & 5.24 & 0.2399 \\
\hline C16:0 & 5326.8 & 5261.2 & 4897.7 & 192.49 & 0.3640 \\
\hline C18:0 & 2337.8 & 2286.9 & 2042.4 & 90.10 & 0.1880 \\
\hline SFA & 8015.8 & 7898.4 & 7276.9 & 285.26 & 0.2882 \\
\hline C16:1 & 903.9 & 930.8 & 879.0 & 29.09 & 0.5286 \\
\hline C18:1 & 11367.9 & 11408.2 & 10574.9 & 428.06 & 0.4129 \\
\hline C20:1 n9 & 210.6 & 214.9 & 180.6 & 10.33 & 0.1765 \\
\hline MUFA & 12482.4 & 12553.9 & 11634.5 & 466.75 & 0.4139 \\
\hline C18:2 n6 & 1988.8 & 1939.4 & 1789.3 & 58.49 & 0.1829 \\
\hline $\mathrm{C} 18: 3 \mathrm{n} 3$ & 179.8 & 191.1 & 164.4 & 10.11 & 0.3126 \\
\hline $\mathrm{C} 20: 2 \mathrm{n} 6$ & 80.9 & 76.0 & 74.4 & 2.28 & 0.2611 \\
\hline $\mathrm{C} 20: 3 \mathrm{n} 6$ & 15.8 & 18.1 & 17.3 & 3.05 & 0.8647 \\
\hline $\mathrm{C} 20: 4 \mathrm{n} 6$ & 64.9 & 55.7 & 59.2 & 3.40 & 0.2982 \\
\hline $\mathrm{C} 22: 4 \mathrm{n} 6$ & 13.6 & 14.3 & 12.7 & 0.51 & 0.2463 \\
\hline n6 & 2163.9 & 2103.5 & 1952.9 & 55.47 & 0.1491 \\
\hline $\mathrm{C} 22: 5 \mathrm{n} 3$ & 34.7 & 42.0 & 30.3 & 4.01 & 0.2635 \\
\hline n3 & 214.5 & 233.1 & 194.8 & 10.23 & 0.1636 \\
\hline PUFA & 2378.4 & 2336.6 & 2147.7 & 85.79 & 0.3045 \\
\hline Total & 22876.6 & 22788.9 & 21059.0 & 814.94 & 0.3395 \\
\hline
\end{tabular}

${ }^{1}$ SFA: saturated fatty acids; MUFA: monounsaturated fatty acids; PUFA: polyunsaturated fatty acids.

${ }^{2}$ SEM: Standard error of the mean.

${ }^{3} p$ value denotes statistical significance among samples. Means followed by different letters are significant different. 
Table 3. Free fatty acids concentrations in sobrassada of Mallorca from black pig dry cured sausages.

\begin{tabular}{|c|c|c|c|c|c|}
\hline Fatty acids $^{1}$ & & & & SFM ${ }^{2}$ & $n^{3}$ \\
\hline$(\mathrm{mg} / 100 \mathrm{~g} \mathrm{dm})$ & S1 & S2 & S3 & & \\
\hline C14:0 & 113.1 & 100.5 & 96.2 & 6.3 & 0.2855 \\
\hline C16:0 & 1406.0 & 1255.7 & 1303.2 & 38.3 & 0.1416 \\
\hline C18:0 & 360.5 & 304.5 & 342.4 & 42.8 & 0.6764 \\
\hline SFA & $1879.6 \mathrm{a}$ & $1660.6 \mathrm{~b}$ & $1741.8 \mathrm{~b}$ & 20.7 & 0.0111 \\
\hline C16:1 & 365.3 & 334.8 & 359.9 & 10.7 & 0.2480 \\
\hline C18:1 & 4580.2 & 4096.2 & 4422.8 & 184.7 & 0.3084 \\
\hline C20:1 n9 & 113.3 & 97.8 & 125.6 & 17.7 & 0.5963 \\
\hline MUFA & 5058.8 & 4528.8 & 4908.3 & 212.9 & 0.3295 \\
\hline C18:2 n6 & 1079.4 & 968.4 & 1019.9 & 45.1 & 0.3500 \\
\hline C18:3 n3 & 107.0 & 105.2 & 109.1 & 4.3 & 0.8213 \\
\hline C20:2 n6 & 44.4 & 41.7 & 44.5 & 2.2 & 0.6279 \\
\hline $\mathrm{C} 20: 3$ n6 & 12.6 & 11.6 & 12.2 & 0.7 & 0.5972 \\
\hline C20:4 n6 & 43.2 & 41.6 & 43.5 & 1.9 & 0.7824 \\
\hline $\mathrm{C} 22: 4$ n 6 & 6.9 & 7.2 & 8.0 & 0.4 & 0.2501 \\
\hline n6 & 1186.5 & 1070.5 & 1128.1 & 49.8 & 0.3804 \\
\hline $\mathrm{C} 22: 5 \mathrm{n} 3$ & 17.6 & 17.7 & 18.5 & 1.0 & 0.8124 \\
\hline n3 & 124.6 & 122.9 & 127.6 & 5.1 & 0.8135 \\
\hline PUFA & 1311.2 & 1193.4 & 1255.7 & 54.83 & 0.4246 \\
\hline Total & 8249.6 & 7382.8 & 7905.8 & 262.1 & 0.2080 \\
\hline
\end{tabular}

${ }^{\mathrm{T}}$ SFA: saturated fatty acids; MUFA: monounsaturated fatty acids; PUFA: polyunsaturated fatty acids.

${ }^{2}$ SEM: Standard error of the mean.

${ }^{3} p$ value denotes statistical significance among samples. Means followed by different letters are significant different. 
Table 4. Volatile and aroma active compounds (expressed as percentage of the total area extracted by HS-SPME) identified in the headspace of sobrassada of Mallorca from black pig dry sausage.

\begin{tabular}{|c|c|c|c|c|c|c|c|c|c|c|}
\hline \multirow[b]{2}{*}{$\mathrm{N}^{1}$} & \multirow[b]{2}{*}{ Compound (\%) } & \multirow{2}{*}{$\begin{array}{c}\mathrm{MS} \\
\mathrm{LRI}^{2}\end{array}$} & \multicolumn{3}{|c|}{ Sobrassada samples ${ }^{3}$} & \multirow{2}{*}{$\begin{array}{c}\text { LRI } \\
\mathrm{GCO}^{4} \\
\text { Standard }\end{array}$} & \multirow{2}{*}{$\begin{array}{c}\text { LRI } \\
\text { GCO }^{5} \\
\end{array}$} & \multirow[b]{2}{*}{ GCO Descriptor } & \multirow[b]{2}{*}{$\mathrm{DF}^{6}$} & \multirow[b]{2}{*}{$\mathrm{RI}^{7}$} \\
\hline & & & $\mathrm{S} 1$ & $\mathrm{~S} 2$ & $\mathrm{~S} 3$ & & & & & \\
\hline 1 & methyl acetate & 549 & $1.37 \mathrm{~b}$ & $3.29 \mathrm{a}$ & $2.90 \mathrm{a}$ & 549 & & & & $\mathrm{y}$ \\
\hline 2 & 2-methyl-propanal & 590 & 0.04 & 0.02 & 0.04 & 591 & 602 & fresh & 2 & $\mathrm{x}$ \\
\hline 3 & hexane & 598 & 0.03 & 0.03 & 0.03 & 600 & & & & $\mathrm{y}$ \\
\hline 4 & 1-propanol & 610 & $1.52 \mathrm{c}$ & $2.90 \mathrm{~b}$ & $3.76 \mathrm{a}$ & 614 & 628 & fresh, herbal & 2 & $\mathrm{x}$ \\
\hline 5 & 2,3 -butanedione & 624 & 0.25 & 0.11 & 0.11 & 632 & 631 & butter & 3 & $\mathrm{x}$ \\
\hline 6 & 2- butanone & 629 & 0.81 & 1.07 & 0.92 & 638 & & & & $\mathrm{y}$ \\
\hline 7 & ethyl acetate & 634 & $3.48 \mathrm{c}$ & $10.81 \mathrm{a}$ & $7.69 \mathrm{~b}$ & 643 & & & & $\mathrm{y}$ \\
\hline 8 & 2- butanol & 642 & $0.38 \mathrm{~b}$ & $2.37 \mathrm{a}$ & $1.81 \mathrm{a}$ & 654 & & & & $\mathrm{y}$ \\
\hline 9 & benzene & 675 & $0.05 \mathrm{a}$ & $0.02 \mathrm{~b}$ & $0.01 \mathrm{~b}$ & 682 & & & & $\mathrm{y}$ \\
\hline 10 & 2-methyl-1-propanol & 680 & 0.07 & 0.09 & 0.04 & 683 & & & & $\mathrm{y}$ \\
\hline 11 & 3-methyl-butanal & 688 & 0.11 & 0.03 & 0.18 & 691 & & & & $\mathrm{y}$ \\
\hline 12 & heptane & 701 & 0.14 & 0.17 & 0.18 & 700 & & & & $\mathrm{y}$ \\
\hline 13 & 2-methyl-butanal & 700 & 0.06 & 0.04 & 0.05 & 699 & & & & $\mathrm{y}$ \\
\hline 14 & acetic acid & 716 & $26.25 \mathrm{~b}$ & $47.58 \mathrm{a}$ & $46.26 \mathrm{a}$ & 702 & 701 & vinegar & 5 & $\mathrm{x}$ \\
\hline 15 & 2-pentanone & 732 & 1.61 & 0.62 & 0.48 & 730 & & & & $\mathrm{y}$ \\
\hline 16 & pentanal & 736 & 0.25 & 0.15 & 0.12 & 735 & & & & $\mathrm{y}$ \\
\hline 17 & ethyl propionate & 743 & $0.11 \mathrm{~b}$ & $0.93 \mathrm{a}$ & $0.84 \mathrm{a}$ & 740 & & & & $\mathrm{y}$ \\
\hline 18 & n-propyl acetate & 748 & $0.29 \mathrm{~b}$ & $1.57 \mathrm{a}$ & $1.82 \mathrm{a}$ & 744 & & & & $\mathrm{y}$ \\
\hline 19 & methyl butyrate & 754 & $0.07 \mathrm{~b}$ & $0.13 \mathrm{a}$ & $0.12 \mathrm{a}$ & 751 & & & & $\mathrm{y}$ \\
\hline 20 & unknown & & & & & & 766 & fresh, cologne & 2 & \\
\hline 21 & dimethyl disulfide & 771 & 0.04 & 0.05 & 0.03 & 773 & 773 & caramel, bouillon, toasted & 2 & $\mathrm{x}$ \\
\hline 22 & 3-hydroxy-2-butanone & 778 & 1.63 & 1.07 & 0.89 & 778 & & & & $\mathrm{y}$ \\
\hline 23 & 1-methyl-1H-pyrrole & 782 & 0.36 & 0.46 & 0.45 & 782 & 777 & toasted, bouillon & 2 & $\mathrm{x}$ \\
\hline 24 & unknown & & & & & & 785 & sweet, strawberry & 3 & \\
\hline 25 & toluene & 788 & $29.15 \mathrm{a}$ & $6.92 \mathrm{~b}$ & $11.29 \mathrm{~b}$ & 789 & & & & $\mathrm{y}$ \\
\hline 26 & 3-methyl-1-butanol & 793 & 0.33 & 0.50 & 0.42 & 789 & & & & $\mathrm{y}$ \\
\hline 27 & octane & 800 & 1.25 & 0.95 & 1.51 & 800 & & & & $\mathrm{y}$ \\
\hline 28 & propanoic acid & 808 & $0.51 \mathrm{a}$ & $0.05 \mathrm{~b}$ & $0.05 \mathrm{~b}$ & 802 & & & & $\mathrm{y}$ \\
\hline 29 & 1-pentanol & 825 & 0.08 & 0.06 & 0.43 & 819 & 810 & pine & 2 & $\mathrm{x}$ \\
\hline 30 & ethyl butyrate & 830 & 0.06 & 0.13 & 0.08 & 825 & 825 & sweet, fruity, stawberry & 3 & $\mathrm{x}$ \\
\hline 31 & 2-hexanone & 834 & 0.18 & 0.08 & 0.09 & 831 & & & & $\mathrm{y}$ \\
\hline 32 & hexanal & 839 & $0.24 \mathrm{a}$ & $0.09 \mathrm{~b}$ & $0.09 \mathrm{~b}$ & 836 & & & & $\mathrm{y}$ \\
\hline 33 & butyl acetate & 846 & $0.03 \mathrm{~b}$ & $0.10 \mathrm{a}$ & $0.15 \mathrm{a}$ & 840 & & & & $\mathrm{y}$ \\
\hline 34 & 2-methyl-pyrazine & 859 & $0.03 \mathrm{a}$ & $0.02 \mathrm{~b}$ & $0.02 \mathrm{~b}$ & 858 & & & & $\mathrm{y}$ \\
\hline 35 & ethyl 2-methyl-butanoate & 877 & $0.01 \mathrm{~b}$ & $0.04 \mathrm{a}$ & $0.02 \mathrm{~b}$ & 872 & 871 & fruit, pineapple & 3 & $\mathrm{x}$ \\
\hline 36 & unknown & & & & & & 872 & cheese & 5 & \\
\hline 37 & ethyl 3-methylbutanoate & 881 & $0.03 \mathrm{~b}$ & $0.06 \mathrm{a}$ & $0.04 \mathrm{~b}$ & 876 & 875 & fruity, orange, geranium & 5 & $\mathrm{x}$ \\
\hline 38 & 2, 3-butanodiol & 882 & 3.47 & 6.55 & 5.40 & 880 & & & & $\mathrm{y}$ \\
\hline 39 & furfural & 894 & 0.02 & 0.02 & 0.01 & 895 & 900 & $\begin{array}{l}\text { bouillon, cooked meat, } \\
\text { vainillin }\end{array}$ & 5 & $\mathrm{x}$ \\
\hline 40 & nonane & 900 & 0.06 & 0.04 & 0.06 & 900 & & & & $\mathrm{y}$ \\
\hline 41 & $\begin{array}{l}\text { 3-methyl-1-butanol } \\
\text { acetate }\end{array}$ & 905 & $0.04 \mathrm{~b}$ & $0.09 \mathrm{a}$ & $0.06 \mathrm{~b}$ & 904 & & & & $\mathrm{y}$ \\
\hline 42 & 1,2-dimethyl-benzene & 916 & $0.18 \mathrm{a}$ & $0.04 \mathrm{~b}$ & $0.03 \mathrm{~b}$ & 918 & & & & $\mathrm{y}$ \\
\hline 43 & 1-hexanol & 922 & $0.14 \mathrm{a}$ & $0.11 \mathrm{a}$ & $0.05 \mathrm{~b}$ & 917 & & & & $\mathrm{y}$ \\
\hline 44 & 2-heptanone & 933 & $5.34 \mathrm{a}$ & $1.47 \mathrm{~b}$ & $2.06 \mathrm{~b}$ & 931 & & & & $\mathrm{y}$ \\
\hline 45 & heptanal & 940 & 0.05 & 0.04 & 0.04 & 936 & & & & $\mathrm{y}$ \\
\hline 46 & 3-methyl-butanoic acid & 940 & 0.30 & 0.34 & 0.33 & 925 & 925 & cheese, feet & 5 & $\mathrm{x}$ \\
\hline 47 & $\alpha$-pinene & 941 & 0.13 & 0.14 & 0.14 & 945 & & & & $\mathrm{y}$ \\
\hline 48 & 2,6-dimethylpyrazine & 943 & $0.14 \mathrm{a}$ & $0.03 \mathrm{~b}$ & $0.04 \mathrm{~b}$ & 944 & & & & $\mathrm{y}$ \\
\hline 49 & 2-heptanol & 947 & 0.40 & 0.28 & 0.40 & 943 & & & & $\mathrm{y}$ \\
\hline
\end{tabular}




\begin{tabular}{|c|c|c|c|c|c|c|c|c|c|}
\hline $\begin{array}{l}50 \\
51\end{array}$ & $\begin{array}{l}\text { 2-butoxy-etanol } \\
\text { unknown }\end{array}$ & 952 & $5.77 \mathrm{a}$ & $0.30 \mathrm{~b}$ & $0.32 \mathrm{~b}$ & 953 & 963 & roasted nuts, fried snacks & 5 \\
\hline 52 & 3- (methylthio)-propanal & 965 & 0.03 & 0.02 & 0.01 & 969 & 968 & cooked potato & 3 \\
\hline 53 & propyl-benzene & 974 & $0.80 \mathrm{a}$ & $0.34 \mathrm{~b}$ & $0.24 \mathrm{~b}$ & & & & \\
\hline 54 & $\beta$-phellandrene & 986 & 1.34 & 1.07 & 1.04 & & & & \\
\hline 55 & decane & 1000 & $0.22 \mathrm{a}$ & $0.08 \mathrm{~b}$ & $0.05 \mathrm{~b}$ & 1000 & & & \\
\hline 56 & $\beta$-myrcene & 1002 & $0.24 \mathrm{a}$ & $0.12 \mathrm{~b}$ & $0.12 \mathrm{~b}$ & 1003 & 1002 & herbal, geranium & 4 \\
\hline 57 & 2-pentyl-furan & 1008 & 0.13 & 0.12 & 0.08 & 1010 & 1008 & cowshed, sulfur & 5 \\
\hline 58 & benzaldehyde & 1013 & $0.13 \mathrm{a}$ & $0.05 \mathrm{~b}$ & $0.04 \mathrm{~b}$ & 1021 & 1021 & fresh, pine, herbal, spices & 5 \\
\hline 59 & 1,2,4-trimethyl-benzene & 1017 & 1.17 & 1.06 & 1.05 & & & & \\
\hline 60 & 3-carene & 1019 & 0.26 & 0.31 & 0.27 & 1027 & 1025 & unpleasant & 2 \\
\hline 61 & heptanol & 1021 & 0.02 & 0.01 & 0.00 & & & & \\
\hline 62 & 6-methyl-5-hepten-2-one & 1031 & $0.09 \mathrm{a}$ & $0.05 \mathrm{~b}$ & $0.03 \mathrm{~b}$ & 1034 & 1032 & resin, pine, herbal, synthetic & 3 \\
\hline 63 & 2-octanone & 1035 & $0.19 \mathrm{a}$ & $0.06 \mathrm{~b}$ & $0.06 \mathrm{~b}$ & 1038 & & & \\
\hline 64 & D-limonene & 1042 & $1.80 \mathrm{a}$ & $0.98 \mathrm{~b}$ & $0.96 \mathrm{~b}$ & 1048 & & & \\
\hline 65 & octanal & 1044 & 0.02 & 0.02 & 0.02 & 1047 & & & \\
\hline 66 & $\begin{array}{l}\text { hexanoic acid }+\alpha- \\
\text { terpinene }\end{array}$ & 1074 & 0.24 & 0.32 & 0.27 & 1065 & 1076 & potato, synthetic, resin & 4 \\
\hline 67 & benzeneacetadehyde & 1104 & 0.17 & 0.12 & 0.13 & 1112 & 1110 & floral, fresh & 2 \\
\hline 68 & phenol & 1109 & 0.03 & 0.02 & 0.02 & 1102 & & & \\
\hline 69 & trans-2-octenal & 1113 & 0.00 & 0.01 & 0.00 & 1117 & 1115 & floral, spices & 2 \\
\hline 70 & tetramethyl-pyrazine & 1117 & 0.05 & 0.04 & 0.04 & 1120 & 1141 & toasted sugar & 3 \\
\hline 71 & 2-nonanone & 1139 & $2.65 \mathrm{a}$ & $0.41 \mathrm{~b}$ & $0.94 \mathrm{~b}$ & 1141 & & & \\
\hline 72 & linalool & 1148 & 0.06 & 0.05 & 0.05 & 1149 & & & \\
\hline 73 & nonanal & 1148 & 0.03 & 0.02 & 0.02 & 1151 & 1155 & citric, plastic & 2 \\
\hline 74 & methyl octanoate & 1155 & 0.09 & 0.09 & 0.07 & 1156 & & & \\
\hline 75 & 2-acetyl pyrrole & 1153 & 0.01 & 0.01 & 0.01 & 1156 & 1178 & roasted nuts, fried snacks & 5 \\
\hline 76 & heptanoic acid & 1166 & 0.00 & 0.01 & 0.00 & 1162 & 1162 & $\begin{array}{l}\text { unpleasant, medicinal, } \\
\text { solvent, rancid }\end{array}$ & 5 \\
\hline 77 & 4-methyl-phenol & 1194 & 0.03 & 0.04 & 0.02 & 1190 & 1190 & manure, cowshed & 6 \\
\hline 78 & phenylethyl alcohol & 1191 & 0.08 & 0.06 & 0.06 & 1195 & 1196 & floral, fresh, synthetic & 2 \\
\hline 79 & unknown & & & & & & 1206 & floral, fresh, pine & 5 \\
\hline 80 & delta-hexalactona & 1206 & 0.01 & 0.01 & 0.01 & 1215 & 1213 & $\begin{array}{l}\text { essential oil, orange peel, } \\
\text { sweet, caramel }\end{array}$ & 5 \\
\hline 81 & (Z)- 2-nonenal & 1218 & 0.01 & 0.01 & 0.01 & 1222 & 1223 & toasted caramel bouillon & 6 \\
\hline 82 & 4-terpineol & 1226 & 0.05 & 0.03 & 0.03 & 1233 & & & \\
\hline 83 & ethyl octanoate & 1227 & 0.03 & 0.04 & 0.03 & 1226 & 1229 & toasted meat synthetic. & 6 \\
\hline 84 & methyl nonanoate & 1258 & 0.01 & 0.01 & 0.01 & 1255 & & & \\
\hline 85 & octanoic acid & 1263 & 0.05 & 0.06 & 0.05 & 1253 & & & \\
\hline 86 & 2-undecanone & 1345 & 0.02 & 0.00 & 0.01 & 1345 & & & \\
\hline 87 & $\beta$-caryophyllene & 1469 & $0.95 \mathrm{a}$ & $0.64 \mathrm{~b}$ & $0.62 \mathrm{~b}$ & 1480 & & & \\
\hline 88 & butylated hydroxy toluene & 1560 & 1.69 & 1.45 & 1.45 & & & & \\
\hline 89 & butylated hydroxyl anisole & 1594 & 0.43 & 0.31 & 0.32 & & & & \\
\hline
\end{tabular}

\footnotetext{
${ }^{1}$ Means followed by different letters are significant different $(p<0.05)$.

${ }^{2}$ Number of the aroma active zones in order of chromatographic elution.

${ }^{2}$ Linear retention indices (LRI) of the compounds eluted from the GC-MS using a DB-624 capillary column.

${ }^{3}$ Linear retention indices of the authentic standards injected in the GC-FID with the same column as above.

${ }^{4}$ Linear retention indices of the aroma detected in the sniffer port.

${ }^{5} \mathrm{DF}$ : detection frequency value.

${ }^{6} \mathrm{R}$ : Reliability of identification; $\mathrm{x}$ : identification by mass spectrum, coincidence with the LRI of an authentic standard and by coincidence with odour description (according to Burdock, 2002, and Acree and Arn, 2004 ); y: identification by mass spectrum and by coincidence with the LRI of an authentic standard, z: tentatively identified by mass spectrum.
} 